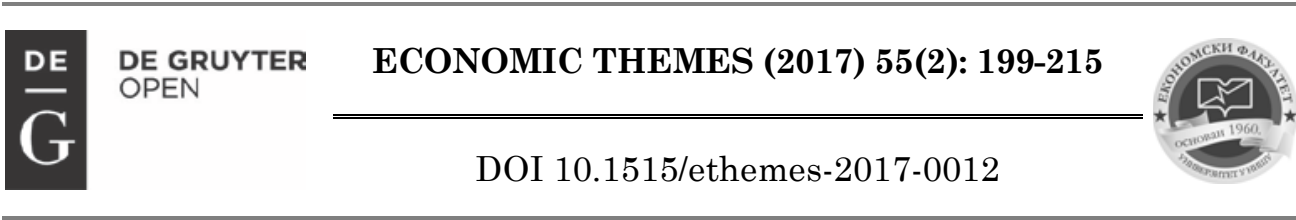

\title{
WINE MARKETING: IMPACT OF DEMOGRAPHIC FACTORS OF SERBIAN CONSUMERS ON THE CHOICE OF WINE
}

\author{
Vladimir Radovanović
}

University of Niš, Faculty of Science and Mathematics, Department of Geography, Republic of Serbia

$\bowtie$ vlad_maxa@yahoo.com

\section{Dejan Ž. Đorđević}

University of Nis, Faculty of Economics, Republic of Serbia

$\triangle$ dejan.djordjevic@eknfak.ni.ac.rs

\section{Jelena Petrović}

University of Niš, Faculty of Science and Mathematics, Department of Geography, Republic of Serbia

$\bowtie$ jelena25@pmf.ni.ac.rs

UDC

663.21:658.

8(497.11)

Original scientific paper
Received: 20.09.2016. Accepted: 24.04.2017.
Abstract: How consumers will behave when buying wine depends on many factors, among which economic, social, demographic, psychological and situational ones are highlighted. Research in wine consumer attitudes in Serbia is aimed at creating appropriate marketing strategies. This paper analyses the influences of demographic factors on wine consumption.Special attention was paid to the impact of the wine characteristics that affect the decision to buy the local or imported wines with geographical origin. It should be added that wine tourism is particularly important in increasing the sales of wine by direct and indirect means.To this aim, 1.705 wine buyers and consumers were interviewed during 2015. Based on Chi-test, it has been proven that the age group affects the decision on the purchase of wine. Understanding consumer motivation is possible through an adequate marketing approach which will provide increased sales of domestic wine and the quicker development of the national market.

Keywords: wine, consumers, demographic factors, marketing, tourism.

JEL classification: M31 


\section{Introduction}

According to the latest data from the Republic Institute for Statistics (2015) cultivated area under vines in Serbia is 22148 ha. 39.13\% is located in Šumadija and Western Serbia, 34.82\% in Southern and Eastern Serbia and 22.59\% in Vojvodina. According to statistical data, the total production of grapes per year is $146.579 \mathrm{t}$ with the average yield of $8 \mathrm{t} / \mathrm{ha}$. It was determined that in the region of Vojvodina the grape varieties which are prevalent are those for the production of wine with geographical origin (1 623 ha of vineyards), as well as in the regions of Šumadija and Western Serbia (2 014 ha), while in Southern and Eastern Serbia (1.402 ha) most present are stone grape varieties (Statistical Office of the Republic of Serbia, http://webrzs.stat.gov.rs.).

Within wine-growing Serbia there are three wine-growing regions: the Region of Central Serbia, Vojvodina Region and the Region of Kosovo and Metohija. Within these three regions there are 22 subregions with 77 vineyards and many wine-growing oases (Pravilnik o rejonizaciji vinogradarskih geografskih proizvodnih područja Srbije, 2015).

Wine production is one of the fastest growing areas in Serbian agriculture, which employs about 100,000 households. Wine production in Republic of Serbia, after a period of stagnation, is about 1.7 million hectoliters on the annual level. There are about 700 types of domestic wines, but the most common grape varieties and wines are: Cabernet Sauvignon, Gamey, Merlot, Pinot Noir, Vranac, Prokupac, etc. The Ministry of Agriculture of Serbia is now enticing wine producers through subsidies for the purchase of coils and equipment for vineyards or wineries (Ministry of Agriculture and Environmental Protection of the Republic of Serbia, http://www.eko.minpolj.gov.rs/).

However, wine trade is not satisfactory - wine export from Serbia is significantly lower than import. The data from 2014 show that the highest volume of wine trade occured within the framework of South-East Europe (CEFTA market). From this market, especially from Macedonia and Montenegro, more than 22 million liters (91\% of total wine imports) were imported, where more than two million liters (8.6\% of total imports) appear on the markets of the European Union. As for wine exports, in 2014 about 6 million liters of wine (about half of the total quantity) went to the market of the Russian Federation and about $28 \%$ to the market of Bosnia and Herzegovina, while exports to the EU market were only 570. 000 liters of wine.

Last studies have shown that the average consumer in Serbia knows very little about wine, i.e. the wine culture. The Ministry of Agriculture of Serbia suggests that the basic difference between the leading wine industry and the Serbian market are more educated consumers as well as greater wine culture. Of all the countries in the region, Slovenia is at the top of per capita wine consumption of 37 liters per 
capita, followed by Croatia with the annual consumption of 28 liters, which is the European average, while Serbia is below average, with the annual consumption of 4 liters, 3 liters of which are imported wine.

Wine is one of the traditional items which the Republic of Serbia produces and exports. Since wine is becoming a global beverage, and the Republic of Serbia has favourable natural conditions for growing vines, it is necessary to apply certain activities for the realisation of marketing concepts of wine sales and exports, in order to increase the market share of domestic wine on the national and international markets. It implies an increase in the export of original high-quality wine in bottles and original packaging, and relative reduction of wine in bulk. At the same time, it is necessary to identify the wine characteristics that affect consumers when making purchasing decisions regarding wine produced by a particular manufacturer on the national and international market. The paper relies on the conducted marketing research of wine consumers, in order to identify the wine characteristic that has a dominant influence on the wine purchasing decision, as well as to analyse the influence of demographic factors of consumers on the importance of the observed characteristics of wine, when making decisions about the purchase of wine.

Understanding the motivation of consumers when purchasing is of vital importance for the implementation of successful marketing strategies, primarily communication strategies, and consequently for the much quicker development of the national market (Vehapi, 2015). Particular attention is devoted to the analysis of the impact of demographic characteristics of consumers on the choice of wine attributes, relevant when making purchasing decisions (Orth et al., 2005; Sanchez \& Gil, 1998).

Even though a large number of foreign authors have studied the motivation factors which condition or hinder the purchase of special wine, such studies are infrequent in Serbia. The paper offers an overview of the existing literature, which outlines the most important results, pertaining to the motivation of consumers on the wine market.

The basic hypothesis in this paper is that the demographic factors of Serbia`s consumers (gender, age, education) affect the decision on the purchase of wine of local or imported origin. It is necessary to analyse the influence of wine attributes on making a decision to purchase and consume wine, in order to understand the behaviour of consumers. In the end, certain concluding remarks are offered and recommendations for the development of successful strategies of the marketing mix instruments are given. 


\section{The History of Viticulture in Serbia}

It is well known that wine has been made since ancient times, but the exact time of its creation and the beginning of its use is unknown. On the basis of Egyptian wall paintings in the tombs of Pharaohs and of hieroglyphic letters it is shown that the cultivation of vines in Egypt was known even as far back as 3500 BC. According to old records about wine culture, it was known in Mesopotamia 4500 years ago. One of the oldest written laws, Hammurabi's law, dating back to around 1700 BC in Babylon, also contains provisions related to viticulture (Marković, 2012). On this basis it is considered that viticulture spread from countries south of the Caspian Sea, i.e. from the East, towards the countries of the West.

On the Balkan Peninsula, ancient Greeks started viticulture. Viticulture in Greece came from Egypt, through Phoenician traders who first brought it to Crete, and then spread to the Peloponnese (3000 years BC). After the Romans conquered Greek colonies, wine experienced a real expansion in the Balkan Peninsula, and therefore in our country as well. Emperor Probus (232 - 282), born in Sirmium Sremska Mitrovica today, held special merits in spreading viticulture in the Balkans. Emperor Probus abolished the law of the Roman Emperor Domitian, which prohibited the planting of vines outside the Apennine Peninsula. Historians state that in the fourth century, viticulture was one of the most important areas of interest of the imperial city of Sirmium.

A special development of viticulture in Serbia occurred during the reign of Nemanjić dynasty from XI until the end of XIV century. In the time of Tzar Dušan a law was passed that would regulate the production and marketing of wine near Prizren, which represents the beginning of geographical origin. During this period, a cup of wine was used for the purpose of political agreements, promises, oaths, customs and law-making (Marković, 2012).

Published Turkish sources testify that in our country viticulture was well developed before the Turkish conquest. Following the invasion of the southern parts of Serbia by the Turks, the Serbian nation moved to the north and, in the time of Tsar Lazar, in the second half of the fourteenth century, Kruševac became the center of Serbian viticulture. During the Turkish conquest and rule, viticulture deteriorated, particularly the cultivation of wine varieties and wine production. Many vineyards with wine grape varieties were destroyed due to the prohibition of wine (alcohol) consumption proscribed by Islam. During this period, planting table varieties was encouraged, so, due to its combination of properties, Serbian native varieties such as prokupac, smederevka, plovdina and tamjanika were saved from extinction (Blagojević, 2004).

After the liberation from the Turks, viticulture in Serbia redeveloped, a significant contribution was achieved by establishing new vineyards under the Obrenović dynasty. The agrarian programme of Miloš Obrenović stated that the 
land belonged to those who farmed it, which resulted in mass immigration and land occupation.

In 1848, during the Austro-Hungarian rule, by the establishment of the Navip basement organised wine production in Serbia began. However, in the midnineteenth century, the development of viticulture in the world was distracted by the appearance of fungal diseases (powdery mildew) and pests (phylloxera) which were transferred from America. Phylloxera destroyed the vineyards in France and other viticultural regions of Europe. At a time when phylloxera was devastating the vineyards of France (1890-1895), Serbia appeared as a producer and exporter of wine in France. Later phylloxera spread over to Serbia as well. In order to renew destroyed vineyards, vine nurseries were established (Smederevo, Negotin, Jagodina) in which the production of cuttings and grafting rootstocks varieties of European grapes was started (Marković, 2012).

Other Serbian rulers are also significant for the development of Serbian viticulture, King Petar I Karađordjević and his son Aleksandar held special merits. Upon inheriting the throne, King Petar I Karađorđević began to form endowment estate at Oplenac from 1903. Dozens of acres of vineyards were planted on the estate and a basement with fine wines was built.

In the 1980s and 1990s the stagnation in viticulture and reduction of the area under vines began. The stagnation was particularly reflected during industrialisation, migration to cities, neglect of vineyards, and also the replacement of vines with more profitable crops such as raspberries and blackberries. The disintegration of Yugoslavia, wars, sanctions and especially the bombing by NATO, led to the complete destruction of viticulture. With the change of the government at the beginning of XXI century in Serbia, most of the former sociallyowned enterprises became private. Some of these companies have maintained the production of grapes, while others turned to other forms of agricultural production. Modern viniculture in Serbia is characterised by a permanent increase in the area under vines, increased productivity and the appearance of many small winegrowing households across the country.

\section{Wine Tourism and the Popularization of Wine}

One of the most effective ways to increase sales and popularisation of wine in general is the wine tourism. In addition to the development of the local community and all the benefits that tourism brings in itself, wine tourism increases the consumption of wine, directly, buying wine from tourists, in tourist destinations or wine households, and indirectly, by selling the same products out of tourist destinations. Wine tourism, as one of the forms of rural tourism, cannot be developed at every geographic area. For its development there must exist the 
geographic and the climatic preconditions adequate for the vine development and the wine production.

This is the reason why wine tourism is connected to the famous vineyard areas in the world, because only at such places can be brought up economic and other effects of such form of tourism.

The last two decades brought the significant minimisation of vine areas in the world. The greatest producer of grapes in the world is Europe, where stand out the following countries: Italy, France, Spain and Germany. The situation is unchanged if we talk about the wine production since, logically, the production unfolds in the most significant vine areas where should be again underlined the European vineyards in France, Italy, Spain, Portugal.

There are a lot of definitions of wine tourism. One of the first was given by Johanson (1997), "wine tourism is a visit to vineyards, wineries, wine festivals and exhibitions that are organized with the purpose of recreation", while Getz and Brown (2006) defined wine tourism as "travel associated with the attraction of wineries and wine-growing regions, types of marketing niche, destination development and opportunities for direct sales and marketing for the wine industry".

These definitions of wine tourism also include a number of features, primarily certain life experiences, supply and demand, education, correspondence with the art, the relationship between food and wine and so on. In addition, wine tourism offers great opportunities to improve the economic, social and cultural values of a region (Getz, 2000). It can therefore be concluded that wine tourist potentials can be presented to tourists in many ways, through events, ethnographic motives, gastronomy, hospitality, etc.

Wine tourism is a concept that is still undergoing substantial development and there is, as well, a great deal to learn about how the two industries can make a positive contribution to each other and to their shared regions throughout the world. They also highlight the fact that wine can provide a major motivating factor for tourists to visit a destination as, more often than not, wine regions tend to be attractive places, and the vineyards themselves are aesthetically pleasing (Đorđević \& Marjanović, 2005).

Wine has become such an important feature of touristic destinations, and a major motivation to visit a region. The geography of wine is an experience of place; its production is intensely geographical, with wines being identified more by location than anything else.

The analysis of wine consumers is especially important in wine tourism, in order to create a potential wine market. This analysis can be carried out through categorising customers, with the help of demographic parameters, such as age, 
gender, education, ethnicity, economical structure, and the like. The second group of parameters consists of psychological characteristics of potential consumers relating to lifestyle, attitudes, prejudices, life philosophy and so on.

Getz (2000) sees triple meaning in wine tourism: as a business strategy that generates the recognisable image of a tourist destination, as a form of behaviour of tourists in the area, wine lovers who visit winemaking regions, and third, as the possibility that wineries have, to educate tourists through direct contact on the value of wine and to sell their products without intermediaries.

In the perceptions of winery managers, however, most wine tourists clearly fall into some middle category - those who claim no special knowledge, but are interested in experience as much as learning, and who also drink wine regularly enough to make planned visits to a winery (Đorđević \& Marjanović, 2005).

In order for the wine tourism to contribute in its on way the economic and social development of rural areas, it must be adopted the basic strategy principles of its planning. If it is harmonically situated in space and adapted to the specifics of certain environment, it can also contribute the active perseverance of the natural and cultural heritage. Dynamic policy of the rural tourism development (within its borders as well as the borders of the wine tourism) implies the determination of short term and mid-term goals, which can be based on the following main ideas (Milenković, 1994):

- Creating entertaining and recreational activities in touristic zones of the rural areas. The touristic arrangement of the rural area must be based on creating the atmosphere which would enable the satisfaction of physical and spiritual needs of modern man. It is necessary to release the country from the negative idea that dwells in the conscience of the city inhabitants, for whom the country is a synonym for boredom and melancholy;

- Creating the accommodation capacities for rent. The accommodation of tourists in a rural area is mostly done in the houses of friends or relatives (for tourists with limited finances) or in weekend houses, the possessions of wealthier city inhabitants. On the other hand, commercial accommodation objects (hotels, bungalows, touristic settlements) in the rural areas are still not enough developed. According to the latter, there are numerous reasons that point to needs to apply measures for stimulation the development of the accommodation capacities for rent in rural communities: the existence of significant constructive funds in the country; the quality of hospitality that can offer the country inhabitants; the increased frequency of visits to rural areas by urban population during weekends and vacations; the increased spacious mobility of tourists (a high degree of motorisation); the rural inhabitants' interest, especially farmers', to provide additional sources of income. The government should undertake adequate measures to stimulate the development of accommodation capacities for rent in rural areas; 
- Promotion and valorisation of the country's touristic idea. The most original aspects of green tourism should be put in the first place, among which the traditional hospitality of country's families, which reflects the social and cultural roots of a certain area.

\section{Literature Overview}

Arsil et al (2014) indicate that the studies of the behaviour of wine consumers should focus on the factors that influence the decision-making process of consumers who buy certain wine. Several authors have attempted to estimate the influence of different attributes of wine on the price of wine (Combris et al., 1997; Geraghty \& Torres, 2009).

It is known that wine is a product whose attributes can be assessed during consumption. Wine attributes include: grape variety, the percentage of blend of different grape varieties, vintage, region of origin, producer, production technology, sensory and biochemical properties, alcohol percentage, price, label, bottle, etc.(Lockshin et al., 2006).

Kotler and Keller (2006) examined the wine market in order to identify the attributes of wines that have the most significant influence on the decision of consumers when purchasing certain wine. A strategic advantage is the existence of a product that has a protected designation of origin as a quality factor of this product (Bruwer \& House, 2003; Bruwer et al, 2012).

One of the main goals of wineries is to increase wine quality (Llevaggi \& Brentani, 2014). Wine quality is an important tool in maintaining and increasing the competitive advantage of wineries on the national and international markets. When assessing the quality of wine, consumers can rely on the geographical origin of wine or on the recognisable brand of wine (Garcia-Galan et al., 2014). According to Farquar (1989), the brand is a symbol that increases the value of the product over its functional value.

Based on the quantification of the impact of the price of alcoholic beverages on wine consumption, Syrovatka et al. (2014) found that the increase in the price of wine did not significantly affect the decrease in wine consumption in the Czech Republic in the period from 1991 to 2012.

Packaging is the result of all activities of designing and manufacturing the product wrapper (Kotler \& Keller, 2006). The consumer's first encounter with the wine in the store actually represents their encounter with the packaging, i.e. bottle or other wine container, and this is exactly what can attract or repel consumers when buying wine.

McKinna (1986) was among the first to examine the geographical segmentation of the wine consumers in South Australia. Thach and Olsen (2006) have done a 
study on the market segmentation in the United States. Customer segmentation can help researchers to analyse the needs of particular segment customers and enable a successful marketing campaign.

As far as demographic segmentation is concerned, according to Lancaster and Stillman (2002), there are four age groups: the Traditionalists (born between 1900 and 1945); Baby Boomers (born between 1946 and 1964); Generation X (born between 1965 and 1977); and Generation Y or Millennials or Echo Boomers (born between 1977 and 2000). Atkin and Thach (2012) demonstrated how the marketing strategies of Millennials differ from older consumers. According to the study conducted by the Council of Vine Market (2003), Millennials make up 35\% of total wine consumption in the US.

One of the goals of our study is to determine the importance of the geographic origin of wine as a factor when making decisions about buying wine concerning Serbia`s consumers. At the same time, special attention was paid to the analysis of the demographic characteristics of consumers, such as: gender, age, and education, as well as their impact on the decision to buy a certain wine.

Monitoring consumer behaviour and determining factors that are important in the decision to purchase certain wine enable the creation of the appropriate marketing strategy. This would allow an increase in sales of locally produced wines in domestic and foreign markets.

\section{Research Methodology, Results and Discussion}

The research for this study was conducted in Serbia in 2015. Consumers of wines were tested by personal contact, or using the face-to-face interview technique. The total of 1,720 wine consumers were surveyed. After the elimination of the incomplete questionnaires, we received a sample of 1,705 questionnaires.

The collected data were analysed using the Statistical Package for the Social Sciences, SPSS. Descriptive statistics and Chi-test were applied in the analysis.

This research was conducted with a view to help Serbia`s producers of wine in selling their products on the domestic market, where there is a large competition in high quality imported wine. The first major question was whether the respondent likes wine, and what the reasons for choosing certain types of wine are. In this part of the survey, the main results from the study of customer behaviour in Southern Serbia wine market are reflected. 
Table 1. Demographic characteristic of wine consumers

\begin{tabular}{|c|c|c|c|}
\hline Characteristics & Definition & $\begin{array}{c}\text { Sample } \\
\text { numbers }\end{array}$ & Frequency (\%) \\
\hline \multirow{3}{*}{ Gender } & Male & 831 & 48.7 \\
\cline { 2 - 4 } & Female & 874 & 51.3 \\
\hline \multirow{4}{*}{ Education Level } & Primary & 57 & 3.3 \\
\cline { 2 - 4 } & Secondary & 798 & 46.8 \\
\cline { 2 - 4 } & University & 850 & 49.9 \\
\hline \multirow{5}{*}{ Age group } & $\begin{array}{c}18-28 \\
(1997-1987)\end{array}$ & 830 & 48.7 \\
\cline { 2 - 4 } & $\begin{array}{c}29-38 \\
(1986-1977)\end{array}$ & 313 & 18.4 \\
\cline { 2 - 4 } & $\begin{array}{c}39-50 \\
(1976-1965)\end{array}$ & 262 & 15.4 \\
\cline { 2 - 4 } & $\begin{array}{c}51-65 \\
(1964-1950)\end{array}$ & 300 & 17.6 \\
\hline
\end{tabular}

Source: Prepared by the authors (SPSS Statistics 19)

Table 1 shows the demographic characteristics of wine consumers in Serbia. The millennials generation is the largest group of wine consumers with a total of 67.1\%. This segment group is divided into two subgroups: Generation $\mathrm{Y}_{1}$ from 1977 to 1986 (18.4\%) and Generation $\mathrm{Y}_{2}$ (48.7\%). The largest number of the Millennials, who were interviewed in this research were students at the University of Niš (Serbia). The age of the wine consumers was from 39 to 50 (Generation X) who constituted 15.4\%, and from 51 to 65 (Baby Boomers generation) constituting $17.6 \%$. According to the gender structure of the respondents, $51 \%$ of the sample were female and $49 \%$ were male. Most of the respondents had higher and secondary education ( $49.9 \%$ and $47 \%)$, and only $3 \%$ respondents had primary education.

Observing the impact of gender of the respondents as well as on the basis of the data from Table 2, it can be concluded that $83.81 \%$ of the respondents prefer to buy local wine, $48.74 \%$ of which were male and $51.26 \%$ were female. 
Table 2. Purchasing wine of local or imported origin by gender

\begin{tabular}{|c|c|c|c|c|c|}
\hline \multicolumn{6}{|c|}{ CROSSTAB } \\
\hline & & & \multicolumn{2}{|c|}{ Gender } & \multirow{2}{*}{ Total } \\
\hline & & & Male & Female & \\
\hline \multirow{8}{*}{ Wine } & \multirow{4}{*}{$\begin{array}{l}\text { Local } \\
\text { origin }\end{array}$} & Count & 696.48 & 732.52 & 1429.00 \\
\hline & & $\begin{array}{l}\text { \% within } \\
\text { wine }\end{array}$ & $48.74 \%$ & $51.26 \%$ & $100.00 \%$ \\
\hline & & $\begin{array}{l}\text { \% within } \\
\text { gender }\end{array}$ & $83.81 \%$ & $83.81 \%$ & $83.80 \%$ \\
\hline & & $\%$ of Total & $40.85 \%$ & $42.96 \%$ & $83.80 \%$ \\
\hline & \multirow{4}{*}{$\begin{array}{c}\text { Imported } \\
\text { origin }\end{array}$} & Count & 134.52 & 141.48 & 276.00 \\
\hline & & $\begin{array}{l}\text { \% within } \\
\text { wine }\end{array}$ & $48.74 \%$ & $51.26 \%$ & $100.00 \%$ \\
\hline & & $\begin{array}{l}\text { \% within } \\
\text { gender }\end{array}$ & $16.19 \%$ & $16.19 \%$ & $16.20 \%$ \\
\hline & & $\%$ of Total & $7.89 \%$ & $8.30 \%$ & $16.20 \%$ \\
\hline \multirow{4}{*}{\multicolumn{2}{|c|}{ Total }} & Count & 831.00 & 874.00 & 1705.00 \\
\hline & & $\begin{array}{c}\text { \% within } \\
\text { wine }\end{array}$ & $48.7 \%$ & $51.3 \%$ & $100.00 \%$ \\
\hline & & $\begin{array}{l}\text { \% within } \\
\text { gender }\end{array}$ & $100.0 \%$ & $100.0 \%$ & $100.00 \%$ \\
\hline & & $\%$ of Total & $48.7 \%$ & $51.3 \%$ & $100.00 \%$ \\
\hline
\end{tabular}

Source: Prepared by the authors (SPSS Statistics 19)

The value of the asym Sig (greater than 0.05) indicates that the gender of consumers is of no significant impact on the decision to buy certain wine.

Table 3. The impact of gender, age and education of consumers on purchasing wine of local or imported origin

\begin{tabular}{|c|c|c|c|c|c|c|}
\hline $\begin{array}{c}\text { Demographic } \\
\text { Characteristics }\end{array}$ & $\begin{array}{c}\text { Value of } \\
\text { Pearson Chi- } \\
\text { Square }\end{array}$ & $\begin{array}{c}\text { Continuity } \\
\text { Correction }\end{array}$ & $\begin{array}{c}\text { Likelihood } \\
\text { Ratio }\end{array}$ & $\begin{array}{c}\text { Linear-by- } \\
\text { Linear } \\
\text { Association }\end{array}$ & $\begin{array}{c}\text { Asym. Sig . } \\
\text { (2-sided) }\end{array}$ & $\begin{array}{c}\text { No. of } \\
\text { Valid } \\
\text { Cases }\end{array}$ \\
\hline Gender & 1.901 & 1.723 & 1.900 & 1.899 & 0.168 & 1705 \\
\hline Age group & 39.473 & $/$ & 37.335 & 0.007 & 0.000 & 1705 \\
\hline Education & 21.853 & $/$ & 22.091 & 2.417 & 0.000 & 1705 \\
\hline
\end{tabular}

Source: Prepared by the authors (SPSS Statistics 19) 
Table 4. Purchasing wine of local or imported origin by age group

\begin{tabular}{|c|c|c|c|c|c|c|c|}
\hline \multicolumn{8}{|c|}{ CROSSTAB } \\
\hline & & & \multicolumn{4}{|c|}{ Age } & \multirow{2}{*}{ Total } \\
\hline & & & $18-28$ & $29-38$ & $39-50$ & $51-65$ & \\
\hline \multirow{8}{*}{ Wine } & \multirow{4}{*}{$\begin{array}{l}\text { Local } \\
\text { origin }\end{array}$} & Count & 795.64 & 262.33 & 207.85 & 263.17 & $\begin{array}{c}1429.0 \\
0\end{array}$ \\
\hline & & $\begin{array}{l}\% \text { within } \\
\text { wine }\end{array}$ & $48.68 \%$ & $18.36 \%$ & $14.55 \%$ & $18.42 \%$ & $\begin{array}{c}100.00 \\
\%\end{array}$ \\
\hline & & $\begin{array}{c}\text { \% within } \\
\text { age }\end{array}$ & $83.81 \%$ & $83.81 \%$ & $83.81 \%$ & $83.81 \%$ & $\begin{array}{c}83.81 \\
\% \\
\end{array}$ \\
\hline & & $\%$ of Total & $40.80 \%$ & $15.39 \%$ & $12.19 \%$ & $15.44 \%$ & $\begin{array}{c}83.81 \\
\% \\
\end{array}$ \\
\hline & \multirow{4}{*}{$\begin{array}{l}\text { Imported } \\
\text { origin }\end{array}$} & Count & 134.36 & 50.67 & 40.15 & 50.83 & 276.00 \\
\hline & & $\begin{array}{l}\text { \% within } \\
\text { wine }\end{array}$ & $48.68 \%$ & $18.36 \%$ & $14.55 \%$ & $18.42 \%$ & $\begin{array}{c}100.00 \\
\%\end{array}$ \\
\hline & & $\begin{array}{l}\text { \% within } \\
\text { age }\end{array}$ & $16.19 \%$ & $16.19 \%$ & $16.19 \%$ & $16.19 \%$ & $\begin{array}{c}16.19 \\
\%\end{array}$ \\
\hline & & $\%$ of Total & $7.88 \%$ & $2.97 \%$ & $2.35 \%$ & $2.98 \%$ & $\begin{array}{c}16.19 \\
\%\end{array}$ \\
\hline \multirow{4}{*}{\multicolumn{2}{|c|}{ Total }} & Count & 830.00 & 830.00 & 313.00 & 248.00 & $\begin{array}{c}1705.0 \\
0\end{array}$ \\
\hline & & $\begin{array}{l}\text { \% within } \\
\text { wine }\end{array}$ & $48.70 \%$ & $48.68 \%$ & $18.36 \%$ & $14.55 \%$ & $\begin{array}{c}100.00 \\
\%\end{array}$ \\
\hline & & $\begin{array}{l}\text { \% within } \\
\text { age }\end{array}$ & 100.00 & $100.00 \%$ & $100.0 \%$ & $\begin{array}{c}100.00 \\
\%\end{array}$ & $\begin{array}{c}100.00 \\
\%\end{array}$ \\
\hline & & $\%$ of Total & $48.7 \%$ & $48.68 \%$ & $18.36 \%$ & $14.55 \%$ & $\begin{array}{c}100.00 \\
\%\end{array}$ \\
\hline
\end{tabular}

Source: Prepared by the authors (SPSS Statistics 19)

Table 4 presents the statistical data on the impact of the age group on the purchase of certain wines. On this basis, it can be concluded that the respondents in Millennial groups (83.81 \%) mainly buy wine of local origin:

On the basis of the value of Sig. in Table 3 (value of Pearson Chi-Square is 39.473 and asym Sig. 0.000), it can be concluded that the age of consumers has a significant impact on the decision to purchase wine of local or imported origin.

Table 5 shows the effect of education on consumer decision when purchasing certain wine: 
Table 5. Purchasing wine of local or imported origin by education

\begin{tabular}{|c|c|c|c|c|c|c|}
\hline \multicolumn{7}{|c|}{ CROSSTAB } \\
\hline & & & \multicolumn{3}{|c|}{ Education } & \multirow{2}{*}{ Total } \\
\hline & & & Elementary & Secondary & University & \\
\hline \multirow{8}{*}{ Wine } & \multirow{4}{*}{$\begin{array}{l}\text { Local } \\
\text { origin }\end{array}$} & Count & 47.77 & 668.82 & 712.40 & 1429.00 \\
\hline & & $\%$ within wine & $3.3 \%$ & 46.80 & $49.85 \%$ & $100.0 \%$ \\
\hline & & $\begin{array}{l}\% \text { within } \\
\text { education }\end{array}$ & $83.81 \%$ & $83.81 \%$ & $83.81 \%$ & $83.81 \%$ \\
\hline & & $\%$ of Total & $2.80 \%$ & $39.23 \%$ & $41.78 \%$ & $83.81 \%$ \\
\hline & \multirow{4}{*}{$\begin{array}{l}\text { Imported } \\
\text { origin }\end{array}$} & Count & 9.23 & 129.18 & 173.60 & 276.00 \\
\hline & & $\%$ within wine & $3.34 \%$ & $46.80 \%$ & $49.85 \%$ & $100.00 \%$ \\
\hline & & $\begin{array}{l}\% \text { within } \\
\text { education }\end{array}$ & $16.19 \%$ & $16.19 \%$ & $16.19 . \%$ & $16.19 \%$ \\
\hline & & $\%$ of Total & $0.54 \%$ & $7.58 \%$ & $8.07 \%$ & $16.19 \%$ \\
\hline \multirow{4}{*}{\multicolumn{2}{|c|}{ Total }} & Count & 57.00 & 798.00 & 850.00 & 1705.00 \\
\hline & & $\%$ within wine & $3.34 \%$ & $46.80 \%$ & $49.85 \%$ & $100.00 \%$ \\
\hline & & $\begin{array}{l}\% \text { within } \\
\text { education }\end{array}$ & $100.0 \%$ & $100.0 \%$ & $100.0 \%$ & $100.00 \%$ \\
\hline & & $\%$ of Total & $3.34 \%$ & $46.80 \%$ & $49.85 \%$ & $100.00 \%$ \\
\hline
\end{tabular}

Source: Prepared by the authors (SPSS Statistics 19)

The results in Table 5 show that the respondents with university and secondary education prefer to decide on the purchase of foreign wines, unlike respondents with primary education, which mainly buy wine of national origin. On the basis of the value of Sig. in Table 3 (value of Pearson Chi-Square is 21.853), it can be concluded that the education of consumers has a significant impact on the decision to purchase wine of local or imported origin. Based on the obtained values of Pearson Chi-square coefficients presented in Table 3, it can be concluded that the age of the respondents influences their decision on the choice of wine; the education of the respondents has less impact, while the gender of the respondents had no significant effect on the choice of a specific origin of wine.

In Table 6, statistics on the impact of the main attributes of wine (quality, brand, price, packing and designation of origin) are given, which can help in the decision on the purchase of certain wines. It was found that $39.8 \%$ of respondents make this decision based on the quality i.e. sensory and biochemical properties such as the colour of wine, $15.4 \%$ based on the brand (symbol or wine brand), 7.6 $\%$ based on the packaging i.e. bottle and cork type and only $5.9 \%$ depending on the country of origin. 
Table 6. Impact of wine attributes on the purchase of wine of local and imported origin

\begin{tabular}{|c|c|c|c|c|c|c|c|c|}
\hline \multicolumn{9}{|c|}{ CROSSTAB } \\
\hline & & & \multicolumn{5}{|c|}{ Wine attributes } & \multirow{2}{*}{ Total } \\
\hline & & & Quality & Brand & Price & Pack. & \begin{tabular}{|l} 
Design. \\
of origin
\end{tabular} & \\
\hline \multirow{8}{*}{ Wine } & \multirow{4}{*}{$\begin{array}{l}\text { Local } \\
\text { origin }\end{array}$} & Count & 570.76 & 230.48 & 410.68 & 112.31 & 104.77 & 1429.00 \\
\hline & & $\%$ within wine & $39.94 \%$ & $16.13 \%$ & $28.74 \%$ & $7.86 \%$ & $7.33 \%$ & $100.00 \%$ \\
\hline & & $\begin{array}{c}\% \text { within wine } \\
\text { attribute }\end{array}$ & $83.81 \%$ & $83.81 \%$ & $83.81 \%$ & $83.81 \%$ & $83.81 \%$ & $83.81 \%$ \\
\hline & & $\%$ of Total & $33.48 \%$ & $13.52 \%$ & $24.09 \%$ & $6.59 \%$ & $6.14 \%$ & $83.81 \%$ \\
\hline & \multirow{4}{*}{$\begin{array}{l}\text { Imported } \\
\text { origin }\end{array}$} & Count & 110.24 & 44.52 & 79.32 & 21.69 & 20.23 & 276 \\
\hline & & $\%$ within wine & $39.94 \%$ & $16.13 \%$ & $28.74 \%$ & $7.86 \%$ & $7.33 \%$ & $100.00 \%$ \\
\hline & & $\begin{array}{c}\% \text { within wine } \\
\text { attribute }\end{array}$ & $16.19 \%$ & $16.19 \%$ & $16.19 \%$ & $16.19 \%$ & $16.19 \%$ & $16.19 \%$ \\
\hline & & $\%$ of Total & $6.47 \%$ & $2.61 \%$ & $4.65 \%$ & $1.27 \%$ & $1.19 \%$ & $16.19 \%$ \\
\hline \multirow{4}{*}{\multicolumn{2}{|c|}{ Total }} & Count & 681.00 & 681.00 & 275.00 & 490.00 & 134.00 & 1705.00 \\
\hline & & $\%$ within wine & $39.94 \%$ & $39.94 \%$ & $16.13 \%$ & $28.74 \%$ & $7.86 \%$ & $100.00 \%$ \\
\hline & & $\begin{array}{c}\text { \% within wine } \\
\text { attribute }\end{array}$ & $100.00 \%$ & $100.00 \%$ & $100.00 \%$ & $100.00 \%$ & $100.00 \%$ & $100.00 \%$ \\
\hline & & $\%$ of Total & $39.94 \%$ & $39.94 \%$ & $16.13 \%$ & $28.74 \%$ & $7.86 \%$ & $100.00 \%$ \\
\hline
\end{tabular}

Source: Prepared by the authors (SPSS Statistics 19)

Regardless whether consumers buy wine of local or imported origin, the highest percentage of respondents when making decision to buy wine based it on its quality. It is founded that a greater number of consumers decide to buy wine on the basis of the quality of national wine as well as its price, while a large number of consumers decide to buy wine of imported origin with a mark.

\section{Conclusion}

Based on the results of Chi-test, the authors demonstrated that the level of education and age of consumers affected the decision to purchase local wines and imported origin, while the gender of the consumer did not have a substantial effect. It was found that the female population buys wine of local origin more in relation to men. In addition, people with higher education more often decide to purchase wine of imported origin compared to lower educated people in Serbia. It is clear that for Serbian consumers the age group has the most significant impact on the choice of wine. 
Research results have shown that when choosing wine, of all wine characteristics, wine quality has the greatest impact on the consumers of both sexes with secondary and higher education.

Knowing that domestic wine production is most affected by the competition in imported wines with a lower price, what is necessary are adequate implementation instruments of promotional mix. It can be said that the competitiveness of local wines can be increased if a Serbian brand is generated. This can be achieved by improving the technology of wine production in order to improve the quality of wines, as well as the formation and implementation of the appropriate wine price strategies, such as price discrimination strategy. Starting from the research results, the conclusion offers recommendations for the successful implementation of the strategy of marketing mix.

Acknowledgement: The research was supported by the Ministry of Education and Science of Serbia, project No.TR 031020.

\section{References}

Arsil, P., Elton, L.\& Bruwer, J. (2014). Perspectives on consumer perceptions of local foods: A view from Indonesia, Journal of International Food \& Agribusiness Marketing, 26(2): 107-124.

Atkin, T. \& Thach, L. (2012). Millenial wine consumers: Rissk perception and information search, Wine Economics and Policy, 1(1): 54-62. 1.

Благојевић, М. (2004).Земљорадња у средњовековној Србији, Београд

Bruwer, J. \& House, M. (2003). Has the era of regional branding arrived for the Australian wine industry? Some perspectives, The Australian \& New Zeland Grapegrower \& winemaner, 479: 56-61.

Bruwer, J., Li, E., Lang, S. \& Chaumont, S. (2012).Perspectives on Consumers`Attitudes to wine `s region of origin in a Restaurant Setting, Journal of Foodservice Business Research, 15(3): 300-318.

Combris, P, Lecocq, S. \& Visser, M. (1997).Estimation of a Hedonic Price Equation for Bordeaux Wine: Does Quality Matter?, The Economic Journal, 107(441): 390-402.

Đorđević D. \& Marjanović V. (2005).Modern Characteristics of Wine Tourism, Contemporary trends in tourism industry, University St. Kliment Ohridski Bitola, Faculty of tourism and hospitality Ohrid

Farquar, P.H. (1989).Managing brand equity, Marketing Research, 1: 24-33.

Garcia-Galan, A., del Moral-Agundez, M. \& Calera-Casquet, C. (2014),Valuation and importance of the extrinsic attributes of the product from the firms' perspective in a Spanish wine protected designation of origin, Spanish Journal of Agricultural Research, 12(3): 568-579.

Getz D. (2000), Explore Wine Tourism: Management, Development, Destinations, New York, Cognizant

Geraghty, S. \& Torres, A. (2009).The Irish wine market: a market segmentation study, International Journal of Wine Business Research, 21(2): 143-154. 
Kotler, Ph. \& Keller, K. (2006).Marketing management, Data Status, Belgrade, ISBN 867478-013.

Lancaster, L. \& Stillman, D. (2002).When generations collide, New York: Harper Collins Publishing

Lockshin, L., Jarvis, W., D’Hauteville, F. \& Perrouty, J. (2006).Using simulations from discrete choice experiments to measure sensitivity to brand, region, price, and awards in wine choice, Food Quality and Preference, 17(3/4): 166-178.

Levaggi, R. \& Brentari, E. (2014). The Hedonic price for Italian red wine: Do chemical and sensory characteristics matter?, Agribusiness, 30(4): 385-397.

Marković N. (2012).Tehnologija gajenja vinove loze, Beograd, Manastir Hilandar

Milenković S. (1994).Poljoprivreda i turizam Srbije, Paraćin, IP "Vuk Karadžić"

Ministry of Agriculture and Environmental Protection of the Republic of Serbia. Available at http://www.eko.minpolj.gov.rs/)

Orth, U., Wolf, M \& Dodd, T. (2005). Dimensions of wine region equity and their impact on consumer preference, Journal of Product \& Brand Management, 14(2): 88-97.

Pravilnik o rejonizaciji vinogradarskih geografskih proizvodnih područja Srbije (2015). Službeni glasnik, br. 45/2015, Beograd, Ministarstvo poljoprivrede i zaštite životne sredine

Sanchez, M. \& Gil, J.M. (1998).Consumer preferences for wine attributes in different retail stores: a conjoint approach, International Journal of Wine Marketing, 10(1): 25-39.

Statistical Office of the Republic of Serbia. Available athttp://webrzs.stat.gov.rs

Syrovátka, P., Chládková, H. \& Žufan, P.N (2014). Wine consumption in the Czech Republic and the prices of alcohol, Agricultural Economics - Czech, 60: 89-98.

Tach, E. \& Olsen, J. (2006).Market segment analysis to target young adult wine drinkers”, Agribusiness, 22(3): 307-322.

Wine market Council (2003).Wine consumer tracking study summary, Available.at http: www//winemarketcouncil.com/research_summary.asp.

Vehapi, S. (2015). A study consumer motives which influence the purchase of organic food in Serbia, Economic Themes, 53(1): 102-118.

\section{VINSKI MARKETING: UTICAJ DEMOGRAFSKIH FAKTORA SRPSKIH POTROŠAČA PRI IZBORU VINA}

Apstrakt: Ponašanje potrošača pri kupovini vina je rezultat komplementarnog rada velikog broja različitih faktora, među kojima su demografski, ekonomski, geografski, socijalni, psihološki i situacioni faktori. U cilju sprovodjenja odgovarajuće marketinške strategije neophodno je sprovesti odgovarajuće marketing istraživanje potrošača vina u Srbiji. Ovaj rad analizira uticaj demografskih faktora potrošača koji utiču na kupovinu određenog vina. Posebna pažnja je posvećena uticaju karakteristika vina koji doprinose odluci o kupovini vina sa geografskog oznakom, domaćeg ili uvoznog porekla. Na osnovu dobijenih rezultat mogu se odrediti koje karakteristike vina imaju najvećeg uticaja na odluku pri kupovini vina. Treba dodati i to, da je vinski tuirzam posebno značajan u povećanju prodaje vina, direktnim i indirektnim putem. Ovo istraživanje doprinosi predviđanju ponašanja potrošača pri kupvini vina u Srbiji. Razumevanje potrošačke motivacije je moguće kroz adekvatan 
marketinški pristup koji će obezbediti povećanu prodaju domaćeg vina i brži razvoj domaćeg tržista

Ključne reči: vino, potrošači, demografski faktori, marketing, turizam.

\section{Authors' biographies}

Vladimir Radovanović is Research Associate at Department of Geography, Faculty of Science and Mathematics, University of Niš and completed his doctoral studies at Faculty of Economics, University of Niš. He has taken in national (Ministry of Education and Science of the Serbia) and international (DAAD, Germany) research projects. In addition, he is an author and coauthor of numerous scientific and research papers in the fields of wine marketing and wine waste management.

Dejan Ž. Đorđević is Associate Professor at Faculty of Economics, University of Niš., where he teaches undergraduate courses in Economic Geography, Tourism Geography and Regional Geography. He has authored numerous scientific and research articles in various kinds of publication and also published scientific and professional papers in domestic and international journals in the fields of Economic and Tourism Geography.

Jelena Petrović is Associate Professor at Department of Geography, Faculty of Science and Mathematics, University of Niš, where she teaches undergraduate course in National Economy and Master's courses such as Introduction to Economics, World Economy, Economy Enterprises and Organizations, Management of Tourism Economy, etc. Her fields of interest include an application of quantitative (statistical) methods in economic research and management of tourism economy. 